Jurnal TIK dalam Pendidikan, Vol. 7 No. 1 Juni 2020, p-ISSN: 2355-4983, e-ISSN: 2407-7488

\title{
IMPLEMENTASI VARIASI METODE KUMON PADA KOMPETENSI DASAR GAYA ANTAR MOLEKUL UNTUK MENINGKATKAN HASIL BELAJAR KIMIA SISWA KELAS XI IPA-1 SMA NEGERI 1 SIBOLGA
}

\author{
Harianto \\ Sekolah Menengah Atas Negeri 1 Sibolga, Sumatera Utara \\ heri_yes@yahoo.com
}

\begin{abstract}
Abstrak: Tujuan Penelitian ini untuk mengetahui peningkatan hasil belajar siswa melalui variasi Metode Kumon pada mata pelajaran kimia materi Gaya Antar Molekul di kelas XI IPA-1 SMA Negeri 1 Sibolga . Jenis penelitian yang digunakan adalah Penelitian Tindakan Kelas. Pendekatan dalam penelitian ini adalah pendekatan kualitatif yang terdiri dari dua siklus. Subjek dalam peneltian ini adalah siswa di kelas XI IPA-1 yang berjumlah 41 orang. Hasil penelitian dengan menggunakan variasi metode Kumon pada mata pelajaran kimia materi Gaya Antar Molekul di kelas XI IPA-1 menunjukkan adanya peningkatan hasil belajar siswa. Dari hasil pre-test diperoleh ketuntasan belajar 41,46\% dengan nilai rata-rata kelas 53,41. Setelah dilaksanakan Siklus I diperoleh ketuntasan belajar sebesar 63,42\% dengan nilai rata-rata kelas 69,02 serta kompetensi guru dalam mengajar sebesar 71,66\% (cukup kompeten). Pada Siklus II Ketuntasan belajar meningkat menjadi 90,24\% dengan nilai rata-rata kelas 82,20 serta kompetensi guru dalam mengajar sebesar 81,66\% (kompeten). Peningkatan hasil belajar dari keadaan awal (pre-test) ke siklus I sebesar 21,96\% dan dari siklus I ke siklus II sebesar 26,82\%.
\end{abstract}

Kata Kunci: variasi metode kumon, kompetensi dasar gaya antar molekul

\begin{abstract}
The purpose of this study is to know the improvement of students' learning outcomes through variations of the Kumon Method on chemistry subjects of Inter-Molecular Style in grade XI IPA-1 SMA Negeri 1 Sibolga. The type of research used is Classroom Action Research. The approach in this study is a qualitative approach consisting of two cycles. Subjects in this study are students in class XI IPA-1, amounting to 41 people. The result of the research using variation of Kumon method on chemistry subjects of Inter-Molecular Style in class XI IPA-1 shows an increase in student learning outcomes. From the pre-test results obtained mastery learning $41.46 \%$ with grade average grade 53.41. After implemented Cycle I, the learning achievement is $63,42 \%$ with the average grade 69,02 and the competence of teacher in teaching equal to 71,66\% (enough competent). In the second cycle of learning completeness increased to $90.24 \%$ with an average grade of 82.20 and teacher competence in teaching of $81.66 \%$ (competent). The increase of learning outcomes from pre-test to cycle I was $21.96 \%$ and from cycle I to cycle II was $26.82 \%$.
\end{abstract}

Keywords: variation of kumon method, basic competence of force between molecules

\section{PENDAHULUAN}

Mata pelajaran kimia perlu diberikan kepada semua peserta didik di tingkat sekolah menengah atas untuk membekali peserta didik dengan kemampuan berpikir logis, analitis, sistematis, kritis dan kreatif, serta kemampuan kerja sama. Kemampuan tersebut harus dimiliki oleh setiap siswa untuk bekal masa depan guna bertahan hidup pada keadaan yang selalu berubah, tidak pasti dan persaingan yang ketat.

Kendatipun kimia sangat penting bagi masa depan siswa, dalam kenyataannya kimia sering dianggap pelajaran yang sulit dan sukar untuk dipahami. Kimia menjadi suatu momok yang sangat menakutkan bagi siswa, kesulitan yang dialami siswa dalam mengerjakan soal-soal kimia adalah salah satu penyebabnya. Hal ini terbukti dari hasil wawancara yang dilakukan guru kelas XI MIA-2 SMA Negeri 1 Stabat mengatakan bahwa, kimia merupakan salah satu pelajaran yang cukup sulit untuk dipelajari, khususnya pada Materi Penentuan Delta $\mathrm{H}$ Pembakaran Bahan Bakar. Hasil belajar siswa kelas XI MIA-2 dalam mata pelajaran kimia pada semester pertama rendah, yaitu 60\% siswa belum mencapai Kriteria Ketuntasan Minimal (KKM) mata pelajaran kimia di sekolah tersebut dengan nilai $\geq 70$.

Banyak faktor yang menyebabkan kimia kurang disukai oleh para siswa, salah satu diantaranya adalah penggunaan metode pembelajaran yang digunakan oleh pengajar masih berorientasi pada metode pembelajaran konvensional yang menempatkan diri peserta didik sebagai pendengar saja seperti metode ceramah, sehingga siswa belajar secara pasif. 
Kita menyadari bahwa tidak ada satu pun metode yang sangat sempurna dalam mengatasi setiap permasalahan dalam proses belajar mengajar di sekolah. Ahli pendidikan juga sependapat bahwa "tidak ada satupun metode mengajar yang dipandang paling baik, karena baik tidaknya metode mengajar sangat tergantung kepada tujuan pengajaran, materi yang diajarkan, jumlah peserta didik, fasilitas penunjang, kesanggupan individual, dan lain-lain”, Danim (2008:34). Jadi metode mengajar yang baik adalah metode mengajar yang sangat tergantung kepada beberapa variabel yang membangun proses belajar mengajar itu.

Salah satu metode yang cukup baik dalam pemecahan masalah yang telah dipaparkan di atas adalah metode Kumon, karena metode ini mempermudah siswa dalam memahami apa yang dipelajarinya melalui latihan secara mandiri. Siswa dilatih untuk belajar sendiri tanpa menyontek milik temannya sendiri, sehingga siswa dapat mengembangkan segala potensi yang dimilikinya. Untuk membuat pembelajaran lebih menarik lagi bagi siswa perlu diberikan selingan ataupun variasi dalam metode Kumon seperti penggunaan media gambar. Seperti yang kita ketahui dalam PBM guru berupaya untuk menyampaikan materi secara rinci dan jelas namun ada kalanya penjelasan tersebut menjadi verbalisme karena guru tidak menggunakan media pembelajaran, sehingga siswa bisa saja salah menanggapi materi yang diajarkan oleh guru, seharusnya guru berupaya untuk menstimulus siswa dari berbagai indera contohnya indera penglihatan dan indera pendengaran sehingga siswa dapat mengerti dan menyerap materi yang diajarkan oleh guru dengan mudah. Dengan mengadakan variasi antara metode kumon dan penggunaan media pembelajaran berupa media gambar diharapkan siswa dapat menguasai materi gaya antar molekul dengan mudah, siswa dapat belajar dengan menggali potensi diri sendiri, mandiri tanpa menyontek dengan temannya, dan lebih percaya diri.

\section{Metode KUMON}

Dalam proses pembelajaran seorang guru harus menguasai metode mengajar yang telah ditetapkannya dalam rencana pelaksanaan pembelajaran (RPP) untuk mencapai tujuan pembelajaran yang telah ditetapkan. Hal tersebut sejalan dengan pendapat Djamarah (2006:46) bahwa " seorang guru tidak akan dapat tugasnya bila tidak menguasai satu pun metode mengajar yang dirumuskan dan dikemukakan para ahli psikologi dan pendidikan".

Uno (2011:7) mendefenisikan "Metode Pembelajaran adalah cara yang digunakan oleh guru dalam menjalankan fungsinya dan merupakan alat untuk mencapai tujuan pembelajaran".

Berdasarkan pendapat diatas maka dapat kita simpulkan bahwa metode adalah cara guru dalam mengajar guna mencapai tujuan pembelajaran yang telah ditetapkan sebelumnya. Salah satu metode yang dapat membantu siswa untuk lebih mudah memahami pelajaran kimia adalah Metode Kumon.

"Metode KUMON adalah suatu metode pembelajaran ditemukan oleh Toru Kumon dari Jepang dengan menggunakan prinsip pembelajaran perseorangan sesuai kemampuan masing-masing siswa dan disusun secara sistematis step by step". (Aqib, 2009:90). Lebih rinci lagi metode Kumon menurut Lukman mengatakan bahwa: Metode KUMON adalah sistem belajar yang memberikan program belajar secara perseorangan sesuai dengan kemampuan masing-masing, yang memungkinkan siswa menggali potensi dirinya dan mengembangkan kemampuannya secara maksimal. Selain itu Lukman menambahkan pembelajaran KUMON adalah pembelajaran yang mengaitkan antar konsep, ketrampilan, kerja individual dan menjaga suasana nyaman-menyenangkan.

Di dalam metode Kumon bahan pelajaran kimia dibuat dengan tujuan membentuk kemampuan dasar anak agar dapat mempelajari kimia dengan kemampuannya sendiri, dalam hal ini guru harus menyusun sendiri bahan pelajaran kimia yang terdiri dari beberapa tahap, bahannya dimulai dari yang paling mudah hingga ke tingkat yang lebih sulit. Namun, kenaikan tingkat kesulitan dirancang hampir tidak terasa. Artinya perubahan bahan pelajaran dibuat sedemikian kecil, bahkan halus dan sistematis. Bahan pelajaran meningkat seiring dengan kemampuan penalaran siswa itu sendiri, sehingga nantinya siswa jarang sekali minta bantuan guru, kesempatan ini dapat dimanfaatkan oleh guru untuk memeriksa hasil pekerjaan siswa lainnya atau membantu siswa lain yang mengalami kesulitan. Cara ini akan membentuk kebiasaan belajar mandiri yang berguna untuk menggali potensi diri-sendiri dan yang paling penting siswa dimudahkan untuk belajar. 
Kunci keberhasilan dalam belajar kimia dengan menggunakan metode KUMON adalah dengan banyak berlatih. Tidak berlebihan bila selama belajar dengan Metode Kumon siswa akan mendapat banyak latihan, Untuk memotivasi siswa dalam belajar guru dapat memberikan pujian bagi siswa atas kesungguhannya sehingga pembelajaran begitu menyenangkan.

Jadi Metode Kumon bukan hanya meningkatkan penguasaan kimia, tapi juga berbagai kemampuan belajar pada siswa, mulai dari konsentrasi dan ketangkasan kerja, semangat kebiasaan belajar mandiri dan kebiasaan belajar setiap hari.

\section{Tahap-tahap penerapan Metode KUMON}

Lukman; Merinci penerapan metode kumon ini kedalam 8 tahap, yaitu: (1) Mulamula, guru menyajikan konsep (diselingi dengan menggunakan media gambar) dan siswa memperhatikan penyajian tersebut. (2) Kemudian siswa mengambil buku saku yang telah disediakan, menyerahkan lembar kerja PR yang sudah dikerjakannya di rumah, dan mengambil lembar kerja yang telah dipersiapkan guru untuk dikerjakan siswa pada hari tersebut. (3) Siswa duduk dan mulai mengerjakan lembar kerjanya. Karena pelajaran diprogram sesuai dengan kemampuan masing-masing, biasanya siswa dapat mengerjakan lembar kerja tersebut dengan lancar. (4) Setelah selesai mengerjakan, lembar kerja diserahkan kepada guru untuk diperiksa dan diberi nilai. Sementara lembar kerjanya dinilai, siswa berlatih dengan alat bantu belajar (dalam hal ini menggunakan media gambar). (5) Setelah lembar kerja selesai diperiksa dan diberi nilai, guru mencatat hasil belajar hari itu pada "Daftar Nilai". Hasil ini nantinya akan dianalisa untuk penyusunan program belajar berikutnya. (6) Bila ada bagian yang masih salah, siswa diminta untuk membetulkan sendiri bagian tersebut. Tujuannya, agar siswa menguasai pelajaran dan tidak mengulangi kesalahan yang sama. (7) Jika siswa salah, maka guru melakukan pendekatan kepada siswa dan menanyakan tentang kesulitan-kesulitan yang dihadapi. (8). Setelah selesai, siswa mengikuti latihan secara lisan. Sebelum pelajaran usai, guru memberikan evaluasi terhadap pekerjaan siswa hari itu dan memberitahu materi yang akan dikerjakan siswa pada hari berikutnya.

Kelebihan dan kekurangan Metode KUMON
Aqib (2009:95) mengemukakan beberapa kelebihan atau keistimewaan metode KUMON, yaitu: "1) Pelajaran disesuaikan dengan kemampuan masing-masing anak, 2) Mulai pelajaran dari hal yang mudah, 3) Membentuk kemandirian belajar".

Sedangkan kelemahan Metode KUMON menurut penulis, yaitu dalam pembelajaran dengan menggunakan metode Kumon, siswa belajar secara perseorangan sehingga memungkinkan tumbuhnya rasa individualisme, dan dalam pembelajaran klasikal yang terdapat banyak siswa akan menyulitkan guru dalam menggunakan metode KUMON, sehingga guru kewalahan dalam pengelolan kelas dan akhirnya penggunaan metode ini tidak optimal.

\section{Variasi Metode KUMON dengan Media Gambar}

Dalam pembelajaran di kelas terdiri dari beragam peserta didik. Peserta didik belajar dengan cara yang berbeda karena faktor keturunan, pengalaman, lingkungan, kepribadian, kecerdasan, bakat, hambatan fisik, emosi dan sosial. Oleh sebab itu ada baiknya kita menggunakan berbagai variasi metode

Variasi berarti selingan, dalam hal ini selingan dalam metode KUMON, sengaja dibuat oleh guru untuk memenuhi kebutuhan belajar siswa terhadap materi gaya antar molekul dalam pelajaran kimia dengan menggunakan media gambar.

Anam menyatakan bahwa: variasi metode pembelajaran dalam mengajar adalah ilmu yang mempelajari cara-cara untuk melakukan aktivitas yang tersistem dari sebuah lingkungan yang terdiri dari pendidik dan peserta didik untuk saling berinteraksi dalam melakukan suatu kegiatan sehingga proses belajar berjalan dengan baik dalam arti tujuan pengajaran tercapai.

Variasi yang dimaksud dalam penelitian ini yaitu dengan menggunakan media gambar, melalui media gambar pembelajaran lebih menarik sehingga memudahkan siswa dalam memahami konsep gaya antar molekul.

Media gambar adalah media yang paling umum dipakai, karena mengandung bahasa umum yang dapat dimengerti dan dinikmati dimana-mana. Seperti pepatah cina mengatakan bahwa sebuah gambar berbicara lebih banyak dari pada seribu kata.

Media gambar mampu menyampaikan pesan-pesan atau informasi yang dituangkan ke 
dalam simbol-simbol komunikasi, simbolsimbol tersebut perlu untuk dipahami dengan benar artinya agar proses penyampaian pesan dapat berhasi dan efisien. Selain itu media gambar mempunyai fungsi untuk menarik perhatian, memperjelas sajian ide, mengilustrasikan atau menghiasi fakta yang mungkin akan cepat dilupakan atau diabaikan bila tidak digambarkan. Ditinjau dari segi ekonomis, media gambar termasuk media yang relatif murah.

Dari pernyataan tersebut dapat kita simpulkan bahwa variasi metode KUMON adalah penggunaan metode KUMON dengan selingan media gambar yang merupakan caracara yang digunakan guru dalam mengajar untuk menciptakan kondisi belajar yang nyaman demi tercapainya tujuan pembelajaran.

Rumusan masalah dalam penelitian ini adalah "Apakah Melalui Variasi Metode Kumon Dapat Meningkatkan Hasil Belajar Kimia Siswa pada Kompetensi Dasar Gaya Antar Molekul di Kelas XI IPA-1 SMA Negeri 1 Sibolga Tahun Ajaran 2016/2017?".

\section{METODE}

Jenis penelitian ini adalah Penelitian Tindakan Kelas (Classroom Action Research) yang bertujuan untuk memecahkan permasalahan nyata yang terjadi di dalam kelas dan sekaligus mencari jawaban atas permasalahan tersebut. Pendekatan yang digunakan adalah pendekatan kuantitaif. Lokasi penelitian ini dilaksanakan di Kelas XI IPA-1 SMA Negeri 1 Sibolga. Subjek penelitian ini adalah siswa kelas XI IPA-2 SMA Negeri 1 Sibolga sebanyak 41 orang siswa. Objek Penelitian ini adalah peningkatan hasil belajar kimia siswa pada Kompetensi Dasar Gaya Antar Molekul di Kelas XI IPA-1 SMA Negeri 1 Sibolga melalui Variasi Metode KUMON.

\section{Teknik Pengumpulan Data}

Alat yang digunakan dalam pengumpulan data penelitian ini adalah observasi dan tes.

1. Observasi

Observasi yang dilakukan merupakan pengamatan terhadap seluruh kegiatan pengajaran yang dilakukan dari awal tindakan sampai berakhirnya penelitian tindakan kelas. Observasi dimaksudkan untuk mengetahui sejauh mana proses pelaksanaan tindakan dapat menghasilkan perubahan yang sesuai dengan yang dikehendaki.

2. Tes

Dalam penelitian ini tes dibagi atas dua tes, yaitu tes kemampuan awal (pre-test) dan tes akhir (post-test). Tes kemampuan awal (pre-test) diberikan sebelum dilaksanakannya penelitian tindakan kelas untuk mengetahui sejauh mana tingkat penguasaan siswa terhadap materi Gaya Antar Molekul, tes awal ini berisikan soal-soal yang dimana berkaitan pembelajaran dengan sub Materi Gaya Antar Molekul, di kelas XI IPA-1 sebanyak 10 soal berbentuk pilihan berganda sedangkan tes akhir diberikan dengan tujuan untuk mengetahui apakah hasil belajar siswa meningkat setelah diberikan pembelajaran dengan menggunakan variasi metode KUMON, tes akhir ini berisikan soal-soal yang dimana berkaitan pembelajaran dengan sub Materi Gaya Antar Molekul di kelas XI IPA-1 sebanyak 10 soal berbentuk pilihan berganda.

\section{Analisis Data}

Guru menganalisis data hasil belajar siswa secara deskrpitif yang bertujuan untuk mendeskripsikan ketuntasan hasil belajar. Data yang dianalisis untuk mendeskripsikan ketuntasan belajar adalah tes awal dan tes akhir, dari hasil jawaban siswa, akan diperoleh tingkat pencapaian hasil belajar. Untuk dapat mengetahuinya guru melakukan pemeriksaan terhadap jawaban siswa dan memberikan skor. Hasil jawaban siswa tersebut kemudian dianalisis untuk menentukan kemampuan siswa yang telah dicapai. Penentuan skor untuk tiap jawaban yang benar adalah 1 dan bobotnya juga 1.

Dari hasil jawaban siswa maka dapat diperoleh tingkat pencapaian hasil belajar. Tingkat kemampuan siswa menyelesaikan soal ditentukan dengan kriteria penentuan tingkat penguasaan siswa terhadap materi yang diajarkan, dengan menggunakan rumus:

a. Rumus yang digunakan untuk menghitung nilai secara individu adalah sebagai berikut:

$$
\text { Nilai }=\frac{\text { Skor yang diperoleh }}{\text { Skor maksimum }} \times 100
$$


Rata-rata kelas

Untuk menentukan nilai rata-rata

kelas ditentukan dengan rumus:

$$
\overline{\mathrm{X}}=\frac{\sum X}{\sum N}
$$

(aqib, 2009:40)

Keterangan:

$\overline{\mathrm{X}} \quad$ : nilai rata-rata kelas

$\sum X:$ Jumlah semua Skor Siswa

$\sum N$ : Jumlah semua siswa

Kriteria:

Jika $\mathrm{x} \geq 70$ hasil belajar tuntas

Jika $\mathrm{x}<70$ hasil belajar belum tuntas

b. Hasil belajar secara klasikal

Untuk mengetahui persentase siswa yang sudah tuntas belajar secara klasikal digunakan rumus:

$\mathrm{P}=\frac{\sum \text { siswa yang tuntas belajar }}{\sum \text { siswa }} \times 100 \%$

(aqib, 2009:41)

Keterangan:

P: angka ketuntasan klasikal

Untuk melihat taraf perubahan proses

belajar siswa dengan nilai yang dicapai adalah

dengan menggunakan standar/penilaian sebagai

berikut:

Tabel 1. Kriteria Tingkat Keberhasilan Belajar Siswa

\begin{tabular}{|c|c|}
\hline $\begin{array}{c}\text { Tingkat Keberhasilan } \\
(\%)\end{array}$ & Arti \\
\hline$>90 \%$ & Sangat tinggi \\
\hline $80-89 \%$ & Tinggi \\
\hline $70-79 \%$ & Sedang \\
\hline $60-69 \%$ & Rendah \\
\hline$<60 \%$ & Sangat Rendah \\
\hline
\end{tabular}

(dalam Aqib, 2004:41)

Dengan melihat hasil ketuntasan belajar siswa baik secara perorangan maupun secara klasikal maka dapat diketahui hasil belajar yang diperoleh siswa. Nilai siswa secara individual yang memenuhi kriteria ketuntasan belajar perorangan berdasarkan KKM yaitu nilai $\geq 70$ dan ketuntasan hasil belajar siswa secara klasikal yang telah ditentukan sebesar $\geq 70 \%$, dengan menggunakan Variasi Metode KUMON hasil belajar siswa pada Kompetensi Dasar Gaya Antar Molekul di Kelas XI IPA-1 SMA Negeri 1 Sibolga Tahun Ajaran 2016/2017 akan meningkat.

\section{HASIL DAN PEMBAHASAN \\ Deskripsi Data Tes Awal (Pre-Test)}

Penelitian ini bertujuan mengetahui hasil belajar kimia tentang Penentuan Delta $\mathrm{H}$ Pembakaran Bahan Bakar dengan menggunakan Variasi Metode KUMON di kelas XI IPA-1 SMA Negeri 1 Sibolga, sebelum diberikan pembelajaran dengan menggunakan variasi metode Kumon, terlebih dahulu siswa diberikan pre-test (tes awal) dengan tujuan untuk mengetahui hasil belajar siswa pada Kompetensi Dasar Gaya Antar Molekul di Kelas XI IPA-1 SMA Negeri 1 Sibolga Tahun Ajaran 2016/2017.

Maka angka Ketuntasan Tingkat keberhasilan belajar siswa secara klasikal dapat dihitung dengan menggunakan rumus:

$$
\mathrm{P}=\frac{\sum \text { siswa yang tuntas belajar }}{\sum \text { siswa }} \times 100 \%
$$

(aqib, 2009:41)

a. Tuntas $=\frac{17}{41} \times 100 \%=43,90 \%$

b. Tidak Tuntas $=\frac{24}{41} \times 100 \%=58,54 \%$

Berdasarkan Tabel 4.1 dapat dilihat bahwa hasil belajar siswa pada pre-test pada Kompetensi Dasar Gaya Antar Molekul di Kelas XI IPA-1 SMA Negeri 1 Sibolga masih tergolong sangat rendah, dengan nilai rata-rata kelas $(53,41)$. Dari 41 orang siswa terdapat $(41,46 \%)$ atau 17 orang siswa yang sudah tuntas dan $(58,54 \%)$ atau 24 orang siswa yang belum tuntas. Berarti secara klasikal angka ketuntasan hasil belajar siswa pada Kompetensi Dasar Gaya Antar Molekul belum tuntas dan tergolong Rendah (lihat kriteria pada tabel 4.1), adapun yang menjadi masalah adalah hasil belajar siswa rendah, siswa belum mampu menyelesaikan soal-soal. Untuk lebih jelasnya perbandingan jumlah siswa yang tuntas dengan yang tidak tuntas pada pre-test dapat kita lihat pada tabel: 
Tabel 2. Perbandingan ketuntasan hasil belajar siswa secara klasikal pada Pre-Test

\begin{tabular}{|c|c|c|c|c|c|}
\hline \multirow[t]{2}{*}{ Keterangan } & \multirow{2}{*}{$\begin{array}{c}\text { Nilai } \\
\text { Rata-Rata } \\
\text { Kelas }\end{array}$} & \multicolumn{2}{|c|}{ Ketuntasan } & \multicolumn{2}{|c|}{ Persentase ketuntasan } \\
\hline & & Tuntas & Tidak Tuntas & Tuntas & Tidak Tuntas \\
\hline Jumlah & 53,41 & 17 siswa & 24 siswa & $41,46 \%$ & $58,54 \%$ \\
\hline
\end{tabular}

\section{Deskripsi Siklus I Perencanaan}

Dari tes awal yang dilakukan ditemukan tingkat ketuntasan hasil belajar siswa ternyata sangat rendah, untuk itu guru membuat alternatif pemecahan masalah terhadap kesulitan-kesulitan yang dialami siswa yaitu dengan menggunakan variasi metode Kumon, pemecahan masalah yang dilakukan yaitu:

1) Guru membuat Rencana Pelaksnaan Pembelajaran dengan Variasi Metode Kumon

2) Mempersiapkan materi ajar kimia berupa pembuatan RRP pembelajaran pada Kompetensi Dasar Gaya Antar Molekul.

3) Membuat lembar observasi yang berisi tentang penilaian proses pembelajaran ketika variasi metode Kumon diterapkan.

4) Menyiapkan penahapan materi pelajaran yang disesuaikan dengan kondisi siswa dan keterbatasan waktu yang dimiliki guru.

5) Guru mempersiapkan buku saku/pedoman bagi siswa dan soal-soal yang berisi penahapan materi yang tercermin pada lembar kerja dan lembar tugas siswa

6) Guru membuat tes hasil belajar siswa Siklus I/post-test I untuk melihat hasil belajar siswa pada mata pelajaran kimia pada Kompetensi Dasar Gaya Antar Molekul.

7) Menyiapkan media gambar yang cocok untuk materi Gaya Antar Molekul.

\section{Pelaksanaan Tindakan}

Pada tahap ini guru bertindak sebagai guru. Kegiatan pembelajaran yang dilakukan merupakan pengembangan dan perencanaan tindakan yang telah direncanakan. Adapun tindakan yang dilaksanakan adalah:

\section{Pertemuan Pertama}

1) Pemanasan-Apersepsi

a. Tanya jawab tentang materi prasyarat yang diketahui oleh siswa kemudian mengarahkan siswa untuk memahami materi prasyarat tersebut.

b. Memotivasi siswa untuk memahami materi yang akan dipelajari dengan menggunakan media gambar.

2) Eksplorasi
Dengan menggunakan media gambar guru, menyajikan materi ataupun konsep pada Materi Gaya Antar Molekul, sub Materi Gaya Antar Molekul, Guru memberikan buku saku (pedoman bagi siswa untuk mengerjakan latihan pada lembar kerja siswa) dan lembar kerja siswa yang berisi Materi Gaya Antar Molekul kemudian siswa mengerjakan lembar kerja siswa secara mandiri.

3) Elaborasi

Dalam kegiatan elaborasi, guru memberikan pendekatan ataupun bimbingan individual bagi siswa yang mengalami kesulitan dalam mengerjakan lembar kerjanya setelah berusaha memperbaikinya sendiri agar lebih paham.

4) Konfirmasi

Guru bersama siswa melakukan tanya jawab untuk meluruskan kesalah pahaman, memberikan penguatan dan penyimpulan.

5) Pembentukan sikap dan perilaku

Dalam menyelesaikan lembar kerja siswa, diharapkan siswa dapat bekerja secara mandiri sesuai dengan kemampuannya masing-masing.

6) Penilaian formatif

Pada pertemuan I guru memberikan Lembar Kerja Siswa dan sebelum selesai guru memberikan Pekerjaan Rumah (PR).

\section{Pertemuan Kedua}

1) Pemanasan-Apersepsi

a. Tanya jawab tentang materi prasyarat yang diketahui oleh siswa kemudian mengarahkan siswa untuk memahami materi prasyarat tersebut.

b. Memotivasi siswa untuk memahami materi yang akan dipelajari dengan menggunakan media gambar.

2) Eksplorasi

Dengan menggunakan media gambar guru, menyajikan materi ataupun konsep pada Materi Gaya Antar Molekul, yang berhubungan dengan persoalan sehari-hari, Guru memberikan buku saku (pedoman bagi siswa untuk mengerjakan latihan pada 
lembar kerja siswa) dan lembar kerja siswa yang berisi materi Gaya Antar Molekul dengan persoalan sehari-hari kemudian siswa mengerjakan lembar kerja siswa secara mandiri.

3) Elaborasi

Dalam kegiatan elaborasi, guru memberikan pendekatan ataupun bimbingan individual bagi siswa yang mengalami kesulitan dalam mengerjakan lembar kerjanya setelah berusaha memperbaikinya sendiri agar lebih paham.

4) Konfirmasi

Guru bersama siswa melakukan tanya jawab untuk meluruskan kesalah pahaman, memberikan penguatan dan penyimpulan.

5) Pembentukan sikap dan perilaku

Dalam menyelesaikan lembar kerja siswa, diharapkan siswa dapat bekerja secara mandiri sesuai dengan kemampuannya masingmasing.

6) Penilaian formatif

Pada pertemuan II ini guru memberikan Tes hasil belajar Siklus I (Post-test I) yang berjumlah 10 soal dalam bentuk pilihan berganda.

\section{Observasi}

Pada tahap obervasi/pengamatan ini dilakukan oleh guru kimia di kelas XI IPA-1, yang mengamati guru yang bertindak sebagai observer yang melaksanakan pembelajaran dengan variasai metode Kumon. Berdasarkan hasil observasi pada saat tahap silklus I guru kurang efisiensi dalam menggunakan waktu dan dalam pelaksanaan pembelajaran kimia dengan menggunakan variasi metode Kumon guru mengalami kewalahan dalam melakukan pendekatan/bimbingan terhadap siswa yang mengalami kesulitan dalam menyelesaikan soalsoal dalam lembar kerja siswa, namun secara keseluruhan pembelajaran yang diberikan guru belum mengalami ketuntasan $(36,59 \%)$ dapat dilihat pada (lampiran 10) dan aktivitas belajar siswa yang sudah mengalami ketuntasan $(63,42 \%)$ dapat dilihat pada (lampiran 14)

\section{Refleksi}

Berdasarkan hasil pengamatan yang telah dilakukan serta pemberian post-test pada siklus I diperoleh hasil pembelajaran sudah lebih baik dari tes awal dan belum mencapai tingkat ketuntasan belajar.

Maka angka Ketuntasan Tingkat keberhasilan belajar siswa secara klasikal dapat dihitung dengan menggunakan rumus:

$$
\mathrm{P}=\frac{\sum \text { siswa yang tuntas belajar }}{\sum \text { siswa }} \times 100 \%
$$

(aqib, 2009:41)

$$
\begin{aligned}
& \text { a. } \text { Tuntas }=\frac{26}{41} \times 100 \%=63,42 \% \\
& \text { b. Tidak Tuntas }=\frac{15}{41} \times 100 \%=36,59 \%
\end{aligned}
$$

Dari tabel 4.3. diketahui nilai rata-ratanya 69,02 hal ini menunjukkan adanya peningkatan hasil belajar siswa kelas XI IPA-1, dari jumlah 41 orang siswa ada 26 orang siswa $(63,42 \%)$ mencapai angka tingkat ketuntasan hasil belajar dan 15 orang siswa $(36,59 \%)$ tidak mencapai ketuntasan hasil belajar. Untuk lebih jelasnya perbandingan jumlah siswa yang tuntas pada siklus I dapat dilihat pada tabel dan diagram berikut:

Tabel 4. Perbandingan Ketuntasan Hasil Belajar Siswa Pada Siklus I

\begin{tabular}{|c|c|c|c|c|c|}
\hline \multirow{2}{*}{ Keterangan } & \multirow{2}{*}{$\begin{array}{c}\text { Nilai } \\
\text { Rata-rata } \\
\text { Kelas }\end{array}$} & \multicolumn{2}{|c|}{ Ketuntasan } & \multicolumn{2}{|c|}{ Persentase ketuntasan } \\
\cline { 3 - 6 } & Tuntas & $\begin{array}{c}\text { Tidak } \\
\text { Tuntas }\end{array}$ & Tuntas & $\begin{array}{c}\text { Tidak } \\
\text { Tuntas }\end{array}$ \\
\hline Jumlah & 69,02 & 26 siswa & 15 siswa & $63,42 \%$ & $36,59 \%$ \\
\hline
\end{tabular}

Dari data tersebut dapat diketahui bahwa angka tingkat keberhasilan hasil belajar siswa secara klasikal tergolong masih Rendah berdasarkan kriteria (tabel 1) dan secara keseluruhan aktivitas siswa meningkat mencapai $(63,42 \%)$ tetapi belum mencapai standar yang telah ditetapkan sehingga perlu diadakan siklus
II untuk itu perlu dilakukan perencanaan kembali untuk melanjutkan ke siklus II, berdasarkan hasil post-test I ini akan digunakan sebagai acuan untuk semakin meningkatkan hasil belajar siswa dalam materi Gaya Antar Molekul. 
Pada siklus I dalam pembelajaran tampak perubahan pola belajar siswa akibat perlakuan pembelajaran dengan menggunakan variasi metode Kumon, sebelum diterapkannya pembelajaran dengan menggunakan variasai metode Kumon terlihat hasil belajar siswa tentang Gaya Antar Molekul tergolong rendah, namun setelah diterapkan pembelajaran dengan menggunakan variasi metode Kumon hasil belajar siswa mengalami peningkatan.

Adapun refleksi kegagalan pada tahap pelaksanaan tindakan yang didapat berdasarkan hasil observasi terhadap seluruh kegiatan pada siklus I, adalah sebagai berikut:

1) Guru mengalami kewalahan dalam pendekatan/terhadap siswa yang mengalami kesulitan dalam menyelesaikan lembar kerja siswa disebabkan hampir sebagian besar siswa kurang paham.

2) Guru kurang efisien dalam penggunaan waktu, sehingga dalam pelaksanaan tindakan guru memerlukan waktu tambahan sekitar 10 menit dari yang telah ditetapkan dalam RPP.

Berdasarkan kegagalan tersebut maka perlu diadakan perbaikan pembelajaran yang diharapkan dapat meningkatkan hasil belajar siswa pada mata pelajaran kimia materi Gaya Antar Molekul, maka akan dilanjutkan pada siklus II.

\section{Deskripsi Siklus II Perencanaan}

Dari hasil siklus I yang sudah diperoleh tergolong sedang, belum mencapai ketuntasan yang diinginkan. Oleh karena itu pada siklus II guru menyiapkan dan mengembangkan materi dalam rencana pelaksanaan pembelajaran dengan lebih baik lagi, menyediakan media gambar yang lebih menarik lagi dan berusaha menggunakan waktu seefisien mungkin.

Adapun rencana yang dipersiapkan oleh guru adalah sebagai berikut:

1. Membuat rencana pelaksanaan pembelajaran (RPP), sesuai dengan Variasi Metode Kumon

2. Mempersiapkan media gambar yang lebih manarik sesuai dengan materi Gaya Antar Molekul

3. Membuat lembar observasi yang berisi tentang penilaian terhadap proses pembelajaran.

\section{PelaksanaanTindakan}

Pelaksanaan tindakan yang dilakukan pada siklus II adalah melaksanakan kegiatan pembelajaran berdasarkan rencana pelaksanaan pembelajaran (RPP) dengan menggunakan variasi metode Kumon yang bertujuan untuk meningkatkan hasil belajar siswa. Pada siklus I hasil belajar yang dicapai secara klasikal masih tergolong rendah, oleh karena itu tindakan yang dilakukan pada siklus II ini adalah sebagai berikut:

\section{Pertemuan ke tiga}

7) Pemanasan -Apersepsi

a. Tanya jawab tentang materi pada pertemuan sebelumnya melalui beberapa soal kemudian mengarahkan siswa untuk memahami konsep-konsep dasar pada materi sebelumnya.

b. Memotivasi siswa untuk memahami materi yang akan dipelajari dengan menggunakan media gambar.

c. Menginformasikan kepada siswa bahwa materi sebelumnya terkait dengan materi baru yang akan dipelajari, atau ada kesamaan dalam pengerjaannya/ penyelesaiannya.

8) Eksplorasi

Dengan menggunakan media gambar guru, menyajikan materi ataupun konsep pada Materi Gaya Antar Molekul, dalam kegiatan eksplorasi ini guru sangat menekankan agar siswa harus mampu menentukan Gaya Antar Molekul kemudian Guru memberikan buku saku (pedoman bagi siswa untuk mengerjakan latihan pada lembar kerja siswa) dan lembar kerja siswa yang berisi materi Gaya Antar Molekul, kemudian siswa mengerjakan lembar kerja siswa secara mandiri.

9) Elaborasi

Dalam kegiatan elaborasi, guru memberikan pendekatan ataupun bimbingan individual bagi siswa yang mengalami kesulitan dalam mengerjakan lembar kerjanya setelah berusaha memperbaikinya sendiri agar lebih paham.

10) Konfirmasi

Guru bersama siswa melakukan tanya jawab untuk meluruskan kesalah pahaman, memberikan penguatan dan penyimpulan.

11) Pembentukan sikap dan perilaku

Dalam menyelesaikan lembar kerja siswa, diharapkan siswa dapat bekerja secara mandiri sesuai dengan kemampuannya masing-masing. 
12) Penilaian formatif

Pada pertemuan III ini guru memberikan Lembar kerja siswa dan sebelum usai pelajaran guru memberikan Pekerjaan Rumah (PR).

\section{Pertemuan Ke empat}

1) Pemanasan-Apersepsi

a. Tanya jawab tentang materi prasyarat yang diketahui oleh siswa kemudian mengarahkan siswa untuk memahami materi prasyarat tersebut.

b. Memotivasi siswa untuk memahami materi yang akan dipelajari dengan menggunakan media gambar.

2) Eksplorasi

Dengan menggunakan media gambar guru, menyajikan materi ataupun konsep pada Materi Gaya Antar Molekul yang berhubungan dengan persoalan sehari-hari, Guru memberikan buku saku (pedoman bagi siswa untuk mengerjakan latihan pada lembar kerja siswa) dan lembar kerja siswa yang berisi materi penggunaan yang berhubungan dengan persoalan sehari-hari kemudian siswa mengerjakan lembar kerja siswa secara mandiri.

3) Elaborasi

Dalam kegiatan elaborasi, guru memberikan pendekatan ataupun bimbingan individual bagi siswa yang mengalami kesulitan dalam mengerjakan lembar kerjanya setelah berusaha memperbaikinya sendiri agar lebih paham.

4) Konfirmasi

Guru bersama siswa melakukan tanya jawab untuk meluruskan kesalah pahaman, memberikan penguatan dan penyimpulan.

5) Pembentukan sikap dan perilaku

Dalam menyelesaikan lembar kerja siswa, diharapkan siswa dapat bekerja secara mandiri sesuai dengan kemampuannya masing-masing.

6) Penilaian formatif
Pada pertemuan II ini guru memberikan Tes hasil belajar II (Post test II) yang berjumlah 10 soal dalam bentuk pilihan berganda.

\section{Observasi}

Pengamatan dilakukan oleh guru wali kelas XI IPA-1 dengan menggunakan lembar observasi terhadap guru, dengan tujuan apakah pelaksanaan tindakan sesuai dengan skenario pembelajaran yang telah dirancang khususnya dalam penggunaan Variasi Metode Kumon dalam pembelajaran.

Berdasarkan hasil pengamatan pada siklus II guru sudah optimal dan kompeten dalam menggunakan variasi metode Kumon $(81,66 \%)$, secara keseluruhan aktivitas siswa meningkat mencapai $79,68 \%$ atau baik.

\section{Refleksi}

Berdasarkan hasil pengamatan yang telah dilakukan serta pemberian post test pada siklus II diperoleh hasil pembelajaran sudah lebih baik dari tes siklus I dan mencapai tingkat keberhasilan belajar siswa secara klasikal sangat tinggi.

Maka angka Ketuntasan Tingkat keberhasilan belajar siswa secara klasikal dapat dihitung dengan menggunakan rumus:

$$
\mathrm{P}=\frac{\sum \text { siswa yang tuntas belajar }}{\sum \text { siswa }} \quad \mathrm{x} \quad 100 \%
$$

(aqib, 2009:41)

a. Tuntas $=\frac{37}{41} \times 100 \%=90,24 \%$

b. Tidak Tuntas $=\frac{4}{41} \times 100 \%=9,76 \%$

Dari tabel 4.5 diketahui nilai rata-ratanya 82,20 hal ini menunjukkan adanya peningkatan hasil belajar siswa kelas XI IPA-1, dari jumlah 41 orang siswa, Ada 37 orang siswa $(90,24 \%)$ mencapai angka tingkat ketuntasan hasil belajar tergolong tinggi (Baik), dan ada 4 orang siswa $(9,76 \%)$ tidak mencapai ketuntasan hasil belajar. Untuk lebih jelasnya perbandingan jumlah siswa yang tuntas pada siklus II dapat dilihat pada tabel dan diagram berikut:

Tabel 6. Perbandingan Ketuntasan Hasil Belajar Siswa Pada Siklus I

\begin{tabular}{|c|c|c|c|c|c|}
\hline \multirow{2}{*}{ Keterangan } & Nilai & \multicolumn{2}{|c|}{ Ketuntasan } & \multicolumn{2}{c|}{ Persentase ketuntasan } \\
\cline { 3 - 6 } & Rata-rata Kelas & Tuntas & Tidak Tuntas & Tuntas & Tidak Tuntas \\
\hline Jumlah & 82,20 & 37 siswa & 4 siswa & $90,24 \%$ & $9,76 \%$ \\
\hline
\end{tabular}


Upaya-upaya yang telah dilakukan pada pembelajaran kimia pada siklus II terjadi peningkatan, dapat dilihat tinggkat keberhasilan siswa secara klasikal sebanyak 37 siswa $(90,24 \%)$ sudah mencapai tingkat keberhasilan yang tinggi (Baik). Karena siswa sudah mencapai tingkat keberhasilan seperti yang diharapkan sehingga tidak perlu melakukan pembelajaran ke siklus berikutnya.

Hal-hal yang dapat direfleksikan dalam siklus II adalah sebagai berikut:

1. Pada siklus II ini guru tidak mengalami kendala yang berarti dalam melakukan pendekatan/bimbingan terhadap siswa yang mengalami kesulitan dalam pembelajaran kimia tentang Gaya Antar Molekul, dikarenakan dalam kegiatan eksplorasi guru menjelaskan dengan baik. Sehingga siswa yang membutuhkan pendekatan/bimbingan mengalami penurunan.

2. Pada siklus II pemanfaatan waktu sudah baik karena telah terencana dengan baik.

3. Nilai ketuntasan belajar secara klasikal mengalami banyak peningkatan mulai dari tes awal sampai dengan tes akhir pada siklus II.

\section{Pembahasan Penelitian}

Pembelajaran kimia dengan menggunakan variasi metode Kumon adalah salah satu cara yang dipilih dan dilaksanakan oleh guru untuk membantu siswa dalam memudahkan mereka mengikuti kegiatan belajar mengajar terutama dalam pembelajaran kimia dengan tujuan akhir yaitu meningkatkan hasil belajar siswa pada mata pelajaran kimia.

Hasil penelitian, pada saat pre-test sebelum diberikan tindakan diperoleh nilai ratarata kelas sebesar 53,41 dengan tingkat keberhasilan belajar siswa secara klasikal sebanyak 17 orang siswa $(41,46 \%)$ ini tergolong dalam tingkat keberhasilan rendah, namun setelah pemberian tindakan pembelajaran melalui variasi metode Kumon yang dilakukan oleh guru pada siklus I diperoleh nilai rata-rata kelas meningkat menjadi 69,02 dengan tingkat keberhasilan belajar siswa secara klasikal sebanyak 26 orang siswa $(63,42 \%)$ yang tergolong dalam tingkat sedang dan aktivitas siswa tergolong cukup baik $(66,13 \%)$. Hal ini berarti terjadi peningkatan keberhasilan yang dapat dilihat dari data pre-test dengan data post- test I yaitu nilai rata-rata siswa meningkat sebesar 15,61 dan peningkatan keberhasilan belajar siswa secara klasikal sebesar 21,95\% namun peningkatan ini belum mencapai standar yang telah ditetapkan, sehingga perlu perbaikan dan pengembangan pada siklus II.

Pada siklus II, dari tes hasil belajar yang diperoleh nilai rata-rata kelas meningkat menjadi 82,20 dengan tingkat keberhasilan belajar siswa secara klasikal sebanyak 37 orang siswa $(90,24 \%)$ yang tergolong dalam tingkat sangat tinggi dan aktivitas siswa tergolong baik $(79,68 \%)$. Hal ini berarti terjadi peningkatan keberhasilan yang dapat dilihat dari data posttest I dengan data post-test II yaitu nilai rata-rata siswa meningkat sebesar 13,20 dan peningkatan keberhasilan belajar siswa secara klasikal sebesar $26,83 \%$ atau 11 orang siswa dan peningkatan ini sudah mencapai standar yang telah ditetapkan dengan nilai siswa secara individual yang memenuhi kriteria ketuntasan belajar perorangan berdasarkan KKM yaitu nilai $\geq 70$ dan ketuntasan hasil belajar siswa secara klasikal yang telah ditentukan sebesar $\geq 70 \%$ siswa tuntas.

Dari hasil penelitian dan pembahasan maka peningkatan hasil belajar siswa pada mata pelajaran kimia di kelas XI IPA-1 SMA Negeri 1 Sibolga melalui Variasi metode Kumon tercapai pada siklus II dan peningkatan hasil belajar siswa baik secara individual dan klasikal telah mencapai kriteria ketuntasan yang telah ditetapkan, sehingga tidak perlu dilanjutkan pada siklus III.

\section{PENUTUP}

Berdasarkan hasil penelitian dan pembahasan yang telah diuraikan pada bagian bab sebelumnya, dapat ditarik beberapa kesimpulan:

1. Pembelajaran kimia dengan menggunakan variasi metode Kumon dapat melatih dan membentuk siswa untuk mandiri, percaya diri serta memudahkan siswa dalam pemahaman mereka terhadap materi Gaya Antar Molekul.

2. Pembelajaran dengan menggunakan variasi metode Kumon dapat meningkatkan hasil belajar siswa pada mata pelajaran kimia. Hal ini dapat dilihat dari data pada saat pre-test ketuntasan belajar siswa secara klasikal hanya sebanyak 17 siswa $(41,46 \%)$ namun setelah pelaksanaan siklus I dengan 
menggunakan variasi metode Kumon diperoleh peningkatan ketuntasan belajar siswa secara klasikal sebesar $21,95 \%$ yaitu $(63,42 \%)$ atau sebanyak 26 siswa. Pada siklus II juga terjadi peningkatan ketuntasan belajar siswa secara klasikal sebesar $26,83 \%$ yaitu menjadi $(90,24 \%)$ atau sebanyak 37 siswa.

3. Variasi metode Kumon merupakan salah satu alternatif untuk memperbaiki proses pembelajaran.

\section{DAFTAR PUSTAKA}

Arikunto, Suharsimi.dkk. 2009. Penelitian Tindakan Kelas. Bumi Aksara: Jakarta.

Depdikbud.1990. Kamus Besar Bahasa Indonesia. Jakarta. Balai Pustaka
Djamarah, Syaiful dan Aswan Zain. 2006. Strategi Belajar Mengajar. Rineka Cipta: Jakarta.

Sanjaya, Wina H. 2005. Pembelajaran dalam Implementasi Kurikulum Berbasis Kompetensi. Kencana: Jakarta.

Suryabrata, Sumadi. 2002. Psikologi Pendidikan: Raja Grafindo Persada: Jakarta.

Syah, Muhibbin. 2003. Psikologi Belajar. Raja Grafindo Persada: Jakarta.

Uno, B Hamzah. 2011. Belajar dengan Pendekatan PAILKEM. Bumi Aksara: Jakarta. 